\title{
A Survey of Liver Cancer Specialists' Views on the National Liver Cancer Screening Program in Korea
}

\author{
Won Sohn ${ }^{1 *}$, Young-Sun Lee ${ }^{2 *}$, Jae Geun Lee ${ }^{3}$, Jihyun An ${ }^{4}$, Eun Sun Jang ${ }^{5}$, Dong Ho Lee ${ }^{6}$, Dong Hyun Sinn \\ 'Department of Internal Medicine, Kangbuk Samsung Hospital, Sungkyunkwan University School of Medicine, Seoul; ${ }^{2}$ Department of \\ Internal Medicine, Korea University College of Medicine, Seoul; ${ }^{3}$ Department of Surgery, Yonsei University College of Medicine, Seoul; \\ ${ }^{4}$ Department of Gastroenterology and Hepatology, Hanyang University College of Medicine, Seoul; ${ }^{5}$ Department of Internal Medicine, \\ Seoul National University Bundang Hospital, Seoul National University College of Medicine, Seongnam; 'Department of Radiology, \\ Seoul National University Hospital, Seoul National University College of Medicine, Seoul; ${ }^{7}$ Department of Medicine, Samsung Medical \\ Center, Sungkyunkwan University School of Medicine, Seoul, Korea
}

Received Jan. 19, 2020

Revised Feb. 10, 2020

Accepted Feb. 14, 2020
Background/Aims: To reduce the cancer burden, the Korean government initiated the National Cancer Control Plan including the National Liver Cancer Screening Program (NLCSP). Ultrasonography examinations and a-fetoprotein tests at six-month intervals are currently offered for high-risk individuals. High-risk individuals are identified by reviewing the National Health Insurance Service claims data for medical use for the past two years using International Classification of Diseases Codes for specific liver disease. We surveyed the attitudes and opinions towards the NLCSP to understand the issues surrounding the NLCSP in Korea.

Methods: Altogether, 90 Korean Liver Cancer Association members participated in online and offline surveys between November and December 2019.

Results: Approximately one-quarter (27\%) of the survey participants rated the NLCSP as very contributing and about two-thirds (68\%) as contributing to some extent toward reducing hepatocellular carcinoma (HCC)-related deaths in Korea. Most (87.8\%) responded that the current process of identifying high-risk individuals needs improvement. Many (78.9\%) were concerned that the current process identifies individuals who use medical services and paradoxically misses those who do not. When asked for the foremost priority for improvement, solving 'duplication issues between the NLCSP and private clinic HCC screening practices' was the most commonly selected choice (23.3\%).

Conclusions: The survey participants positively rated the role of the NLCSP in reducing liver cancer deaths. However, many participants rated the NCLSP as needing improvement in all areas. This survey can be a relevant resource for future health policy decisions regarding the NLCSP in Korea. (J Liver Cancer 2020;20:53-59)

Keywords: Hepatocellular carcinoma; National Cancer Screening Program; Survey

\section{Corresponding author : Dong Hyun Sinn}

Department of Medicine, Samsung Medical Center, Sungkyunkwan University School of Medicine, 81 Irwon-ro, Gangnam-gu, Seoul 06351, Korea

Tel. +82-2-3410-3409, Fax. +82-2-3410-6983

E-mail; dh.sinn@samsung.com

https://orcid.org/0000-0002-7126-5554

\section{INTRODUCTION}

Liver cancer is the sixth most common cancer (fourth in men and sixth in women) and the second-largest cause of cancer mortality in South Korea. ${ }^{1}$ A total of 15,771 cases

\footnotetext{
*The first two authors contributed equally to this study.
} 
(11,774 men and 3,997 women) were identified, with an agestandardized incidence rate of 18.0 persons per 100,000 (29.2 in men and 7.9 in women) in 2016. ${ }^{2}$ The mortality from liver cancer was 10,721 (7,982 in men and 2,739 in women) in 2017. ${ }^{2}$ To reduce the cancer burden, the Korean government initiated a comprehensive National Cancer Control Plan in 1996. ${ }^{3}$ As part of this plan, the National Cancer Screening Program was launched in 1999. ${ }^{4,5}$ In terms of liver cancer screening, the National Liver Cancer Screening Program (NLCSP) began in 2003 by offering an ultrasonography (US) examination and an $\alpha$-fetoprotein (AFP) test for people aged 40 years and over who were hepatitis B surface antigen (HBsAg) or anti-hepatitis $\mathrm{C}$ virus (HCV)-positive or had liver cirrhosis. The tests were offered at six-month intervals from 2003 to 2011, at one-year intervals from 2012 to 2015, and at six-month intervals since 2016 (https://www.g-health.kr/ portal/index.do, accessed at December 21, 2019).

The stage at diagnosis is an important prognostic factor for cancer patient survival. ${ }^{6}$ The five-year relative survival rate is high for localized Surveillance, Epidemiology, and End Results (SEER) stage liver cancer (42.8\%) and dismal (2.5\%) for distant SEER stage liver cancer. ${ }^{7}$ Compared to the US SEER data, Korean patients had better stage distribution and stage-specific survival rates, which the authors suggested might be the result of contributions by the National Cancer Screening Program. ${ }^{7}$ However, data on the efficacy of the NLCSP is very limited.

The Korean Liver Cancer Association (KLCA) is a leading, multidisciplinary society promoting research in liver cancerrelated disciplines, thereby providing a platform for the exchange of knowledge and information and suggesting scientific evidence and guidelines needed to overcome liver cancer with the aim of contributing toward public health. This study conducted a survey of KLCA members to assess their insights and opinions on the NLCSP, understand issues regarding the NLCSP, and provide relevant information for health policy decision-making in Korea.

\section{METHODS}

\section{Study population and design}

This survey study was conducted by a project committee of the KLCA. The first e-mail requesting participation in the online survey was sent to 735 KLCA members on November 25, 2019. Fifty-three members responded and completed the online survey. The second e-mail requesting participation in the online survey was sent on December 03,2019, to which 18 members responded and completed the online survey. Lastly, a printed survey was prepared and participation was requested from 70 KLCA members who attended the KLCA single-topic conference held on December 13, 2019. Nineteen members completed the printed survey form. Finally, 90 KLCA members participated in this survey study. The baseline characteristics of the survey participants are summarized in Table 1. This study corresponds to an institutional review board approval waiver as only de-identified survey results were used.

Table 1. Baseline characteristics of the survey participants

\begin{tabular}{lc}
\hline Variable & Value $(\mathbf{n}=\mathbf{9 0})$ \\
\hline Sub-specialty & $72(80.0)$ \\
Hepatology & $11(12.2)$ \\
Surgery & $3(3.3)$ \\
Radiology & $2(2.2)$ \\
Radiation oncology & $2(2.2)$ \\
General internist & $2006(1983-2019)$ \\
Year of board-certificate acquisition & \\
(median, range) & $20(22.2)$ \\
Years of sub-specialty experience & $36(40.0)$ \\
Less than 10 years & $34(37.8)$ \\
10 to 19 years & \\
More than 20 years & $79(87.8)$ \\
Workplace & $8(8.9)$ \\
University hospital & $2(2.2)$ \\
General hospital & $1(1.1)$ \\
Private clinic & \\
Government-affiliated agency &
\end{tabular}

Values are presented as number (\%) unless otherwise indicated. 


\section{Survey variables}

The survey comprised three parts. The first part consisted of three questions on sub-specialty, acquisition year of the medical sub-specialty, and place of work. The second part consisted of seven questions asking the KLCA member's assessment of the status of the NLCSP in Korea. The third part consisted of six questions asking for the KLCA member's opinion on how the NLCSP could be improved. A complete survey (in the Korean language) can be found in Supplementary materials.

\section{Statistical analyses}

The results are summarized as median (quartile) or number (\%), as appropriate. We also tested whether opinions differed by sub-specialty or year of experience. $t$-, chi-square, or Fisher's exact tests were used for comparisons, as appropriate. $P<0.05$ was considered significant.

\section{RESULTS}

\section{Assessment of status by KLCA members}

Ninety-nine percent of the participating KLCA members agreed that hepatocellular carcinoma (HCC) surveillance in high-risk patients lowers the risk of HCC-related death (Fig. 1). Regarding the NLCSP in Korea, 99\% reported that they knew the current NLCSP. When asked about the NLCSP's role in Korea, 95\% responded that the NLCSP contributes to lowering the risk of HCC-related deaths in Korea (Fig. 1). When asked, "How many points do you give the NLCSP?" (lowest 0 points-highest 10 points), the median point was 7 (range, 2-10). The mean points were lower in members with more than 10 years of experience than that in those with less than 10 years of experience $(6.96 \pm 1.51$ vs. $7.76 \pm 1.10$, $P=0.009$ ). When the analysis was limited to 72 hepatologists, 30 had less than 10 years of experience, while 42 had more than 10 years of experience. Hepatologists with more experience rated the NLCSP more negatively (Supplementary Table 1). However, there were no significant differences in opinions on the target group, target group identification process, or priority for improvement except for agreement rates on the starting age for surveillance and the reasons why the selection process needs improvement (Supplementary Table 1).

\section{Assessment of target groups}

Currently, the NLCSP offers liver US and serum AFP mea-

\begin{abstract}
Do you agree that hepatocellular carcinoma surveillance in high risk patients can lower the risk of hepatocellular carcinoma-related death?
\end{abstract}

\section{Do you know about the current National Liver Cancer Screening Program in Korea?}

Do you think the National Liver Cancer Screening Program currently implemented in Korea contributes in lowering hepatocellular carcinomarelated deaths?

$\begin{array}{lll}\text { Very agree } & \text { Agree Disagree }\end{array}$

\section{1}

Know very well

79
28

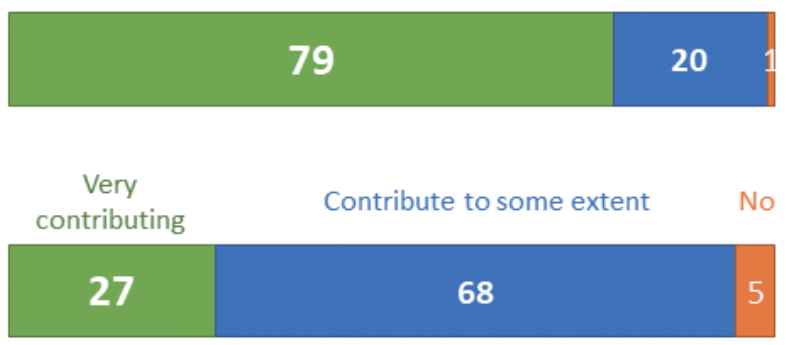

Figure 1. Survey participant assessment of the status of the National Liver Cancer Screening Program. Values are presented as \%. 
surement every six months for high-risk individuals (adults older than 40 years with cirrhosis, chronic hepatitis B virus [HBV], or HCV infection, according to https://www.ghealth.kr/portal/index.do [accessed December 21, 2019]). When asked, $5.6 \%, 57.8 \%, 25.6 \%$, and $1.1 \%$ of survey participants responded that the current target populations were very appropriate, appropriate, inappropriate, and very inappropriate target populations for the NLCSP, respectively. Specifically, 22.2\% responded that cirrhosis over 40 years of age was an inappropriate target, $20 \%$ responded that chronic HBV infection over 40 years of age was inappropriate, and $30 \%$ responded that chronic HCV infection over 40 years of age was an inappropriate target. Six opinions on 'HCC surveillance target' were selected by the project committee members and asked for agreement. The agreement rates ranged from $8.9 \%$ to $82.2 \%$ for each question (Table 2).

\section{Assessment of the target group identification process}

In the NLCSP, the target population (high-risk individuals) is identified by reviewing National Health Insurance Service (NHIS) claims data. The NHIS in Korea is a single-payer universal health system that maintains claims data on all reimbursed inpatient and outpatient visits, procedures, and prescriptions. These claims data are coded using the International Classification of Diseases, Tenth Revision (ICD-10) and the Korean Drug and Anatomical Therapeutic Chemical Codes. The NLCSP identifies high-risk individuals, defined as having NHIS claims for the past two years with the disease classification codes shown in Table 3.

Fifty percent of survey participants responded that they were aware of the target population selection process of the NLCSP. When asked whether this selection process needed

Table 2. Agreements in opinions regarding hepatocellular carcinoma surveillance targets

\begin{tabular}{lc}
\hline Question & Agreement (\%) \\
\hline Surveillance target & 82.2 \\
Patients with liver cirrhosis should be included as surveillance targets regardless of age & 13.3 \\
The starting age for surveillance should differ between men and women & 72.2 \\
Chronic hepatitis patients (e.g., fatty liver, alcoholic liver disease) with advanced fibrosis should be surveillance targets & 17.8 \\
regardless of age & 30.0 \\
Anti-hepatitis C virus-positive patients without advanced fibrosis should not be included as -surveillance targets & \\
regardless of age & 8.9 \\
Chronic hepatitis C patients who achieved sustained virological response and without advanced fibrosis should not be & \\
included as surveillance targets regardless of age & 40.0 \\
Chronic hepatitis B patients without advanced fibrosis should not be included as surveillance targets regardless of age & 42.2 \\
Opinions on the target population selection process & 50.0 \\
Disease classification codes used to select the target population should be simplified & \\
Register target population as cancer or rare/incurable disease & \\
Minimize national program and increase private sector program using more incentives & \\
\hline
\end{tabular}

Table 3. Disease classification codes defining target populations in the National Liver Cancer Screening Program

\begin{tabular}{lc}
\hline Disease entity & \multicolumn{1}{c}{ Classification code } \\
\hline Liver cirrhosis (* indicate $0,1,2,9)$ & $\mathrm{K} 702, \mathrm{~K} 703(\mathrm{~K} 7030, \mathrm{~K} 7031), \mathrm{K} 74, \mathrm{~K} 740\left(\mathrm{~K} 740^{*}\right), \mathrm{K} 741\left(\mathrm{~K} 741^{*}\right), \mathrm{K} 742\left(\mathrm{~K} 742^{*}\right)$, \\
& $\mathrm{K} 743\left(\mathrm{~K} 743^{*}\right), \mathrm{K} 744\left(\mathrm{~K} 744^{*}\right), \mathrm{K} 745\left(\mathrm{~K} 745^{*}\right), \mathrm{K} 746\left(\mathrm{~K} 746^{*}\right), \mathrm{K} 765, \mathrm{~K} 766$ \\
\hline Positive for hepatitis B surface antigen or hepatitis C virus antibody & $\mathrm{B} 18, \mathrm{~B} 180, \mathrm{~B} 181$ (B1810, B1818), B182, B188, B189, Z225 \\
\hline Chronic liver disease due to hepatitis B virus or hepatitis C virus & $\mathrm{B} 19, \mathrm{~B} 190, \mathrm{~B} 199$ \\
\hline
\end{tabular}


improvement, $20 \%, 67.8 \%$, and $10 \%$ responded that improvement was very necessary, necessary, and not necessary, respectively, while two participants $(2.2 \%)$ did not respond. When asked 'Why does the selection process need improvement?', $58.9 \%$ agreed that the screening targets identified by disease classification codes may not match true surveillance targets, $17.8 \%$ agreed that there was a privacy violation problem and $78.9 \%$ agreed that the current process identifies individuals who use medical services, paradoxically missing individuals who do not. Three opinions on 'How the target population selection process can be improved' were selected by the project committee members and asked for agreement. The agreement rates ranged from $40.0 \%$ to $50.0 \%$ for each question (Table 2).

\section{Assessment of priorities for improvement}

When asked for the foremost priority for improvement, solving duplication issues between the NLCSP and private clinic HCC screening practices were the most commonly selected choices $(23.3 \%)$, followed by improving surveillance methods (e.g., allowing the use of computed tomography or magnetic resonance imaging, allowing the use of other tumor markers, and allowing intensive surveillance at short-term intervals) (21.1\%), improving low screening rates (16.7\%), improving the target identification process (14.4\%), improving the definition of the target population (13.3\%), and improving the quality of the NLCSP (8.9\%) (Fig. 2). For each

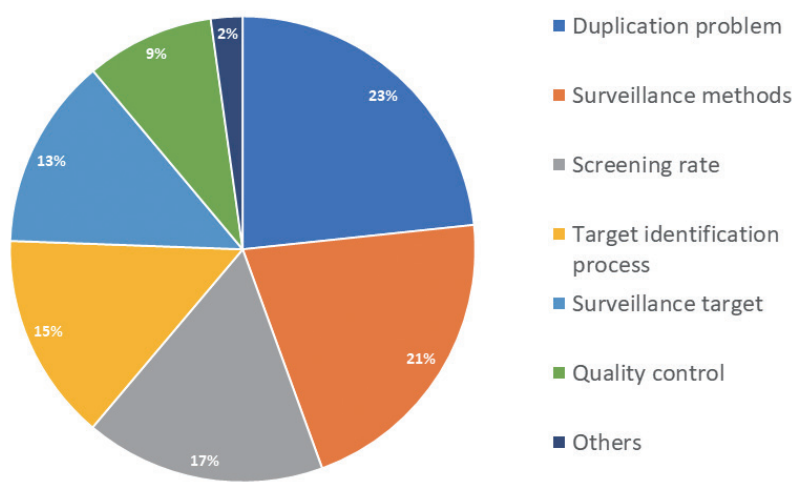

Figure 2. Assessment of the priority for improvement of the National Liver Cancer Screening Program according to survey participants. specific area, $50.0 \%$ to $65.6 \%$ of the survey participants responded that improvement was needed (Fig. 3). There were no differences in the foremost priorities according to the respondents' years of experience, sub-specialties, or workplace (data not shown).

\section{DISCUSSION}

In this survey, $99 \%$ of survey participants agreed that HCC surveillance in high-risk patients could lower the risk of HCC-related death (71\% strongly agreed; $28 \%$ agreed). Ninety-five percent also agreed that the NLCSP helps to reduce the HCC mortality rate in Korea. Yet, only about onequarter $(27 \%)$ answered that the NLCSP is very contributing, while two-thirds of the survey participants $(68 \%)$ rated the NLCSP as contributing to the reduction only to some extent. There was a large gap between belief (71\% strongly agreed that HCC surveillance can lower the risk of HCC-related death) and the actual role of the NLCSP (27\% rated that the NLCSP highly contributed to reducing HCC mortality in Korea). The median score of the current NLCSP was 7 points (max 10 points). It suggests that the survey participants think HCC surveillance can reduce the risk of HCC-related death, but that the NLCSP is not playing a sufficient role.

Several issues have been raised regarding the NLCSP in Korea. A lowered mortality risk (hazard ratio, 0.78; 95\% confidence interval, 0.76 to 0.80 ) was recently reported

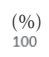

$(\%)$
100

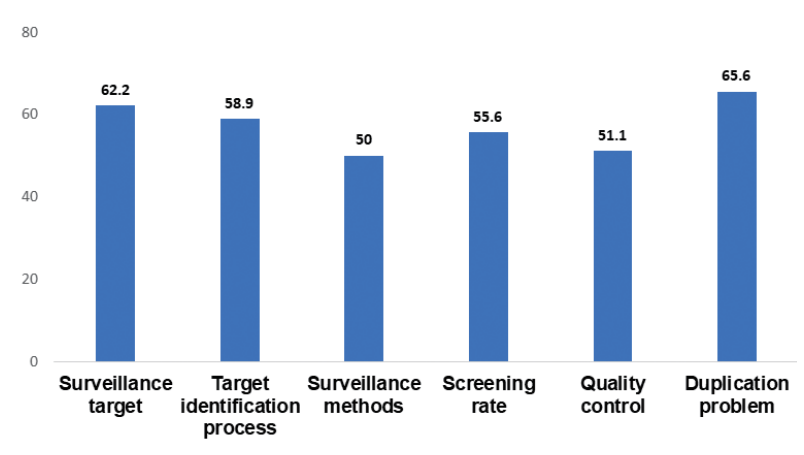

Figure 3. Assessment of the needs for improvement in certain areas of the National Liver Cancer Screening Program according to survey participants. 
among patients who participated in the NLCSP once within two years prior to the diagnosis of liver cancer compared to those who did not participate in the NLCSP, ${ }^{8}$ indicating the potential role of the NLCSP in reducing HCC-related mortality. However, other studies reported poor efficacy of the NLCSP. A study that assessed the 2010 National Cancer Screening Program reported very poor performance of the NLCSP. The positive predictive value was only $5.7 \%$ and the sensitivity was $41.3 \%,{ }^{9}$ meaning that the NLCSP program is not very effective despite the tremendous amount of government funding. A study from a single healthcare center reported that many ( $46 \%$ of NLCSP participants) individuals were inaccurately identified as the NLCSP target population. ${ }^{10}$ Another cohort study of 541 chronic hepatitis B patients who participated in the NLCSP reported that tumors were detected in only nine of 16 patients (56.3\%) under the NLCSP, whereas tumors were detected in seven of 16 patients (43.7\%) by computed tomography or magnetic resonance imaging evaluation outside of the NLCSP. ${ }^{11}$ The participant rates for the NLCSP increased steadily from 13.2\% in 2003 to $39.5 \%$ in $2012^{4}$ but were lowest (33.6\%) compared to other cancers (stomach, colorectal, breast and cervical cancer; $73.6 \%, 55.6 \%, 59.7 \%$ and $67.0 \%$, respectively) in 2013. ${ }^{12}$ The quality of US screening was demonstrated to be sub-optimal in 143/685 hospitals (20.8\%) and 645/1,985 (32.5\%) private clinics that failed to pass quality assurance evaluation for liver cancer screening by US. ${ }^{13}$ In this survey study, most of the survey participants (87.8\%) responded that the current target group identification process requires improvement. Most (78.9\%) were also concerned about missing surveillance targets by using disease classification codes of NHIS claims data for identification. In this survey, more than $50 \%$ of respondents agreed that areas of the NLCSP need improvement (Fig. 3). It is clear that the NLCSP warrants further improvement.

Regarding suggestions to improve the NLCSP, a high rate of agreement was observed on two surveillance targets. The majority of respondents (82.2\%) agreed that patients with liver cirrhosis should be included regardless of age. In fact, the Korean guideline for HCC surveillance recommends surveillance for those with $\mathrm{HBV}$ or $\mathrm{HCV}$ infection or cirrhosis from 40 years of age or at the time of cirrhosis diagnosis. ${ }^{14}$ The reason why the NLCSP is provided for those only aged over 40 years remains unclear and cirrhosis patients should be included in the NLCSP regardless of age. Most (72.2\%) participants also agreed that the NLCSP should include chronic hepatitis patients with advanced fibrosis as these patients are at high risk for HCC. ${ }^{15,16}$ Inclusion of these patients should be considered for the first candidate group when expanding the NLCSP. In terms of the target group identification process, none of the three suggestions for improving the surveillance target selection process achieved high agreement rates (Table 2). Thus, further studies are needed to determine how to improve the surveillance target selection process. Opinions were diverse regarding the foremost priority for improvement (Fig. 2), with solving duplication issues between the NLCSP and private clinic HCC screening practices receiving the most choices $(23.3 \%)$. Efforts to improve the NLCSP are urgently needed.

This study had some limitations. The fairness of survey items and evaluation methods has not been validated by professional survey researchers and not guided by a theoretical framework. The survey form was sent to 735 KLCA members; however, the overall response rate was low (12.2\%) and may not represent the opinions of all KLCA members. Specifically, the respondents included 72 of 368 hepatologists (19.6\%); 11 of 127 surgeons (8.7\%); 3 of 143 radiologists (2.1\%); and 4 of 97 radiation oncologists, pathologists, and other specialties (4.1\%). Most of the survey participants $(87.8 \%)$ worked in university hospitals and hepatologists comprised $80.0 \%$ of participants. The NLCSP is widely practiced by physicians in many specialties and is not only performed in university hospitals. Opinions from other practice areas are needed. The survey was conducted in Korean; hence, its generalizability to other countries with different cultural and medical backgrounds is limited. The survey asked for expert opinions without providing detailed data on the NLCSP in Korea (program cost, HCC diagnosis rate, true positive rate, false-positive rate, false-negative rate, participation rate, etc.). Thus, the survey participants may have under- or over-estimated the actual contributions of the NLCSP in reducing liver cancer mortality in Korea. The strength of 
this survey is that it is the first structured and organized report on the views of liver cancer specialists of the NLCSP in Korea.

In summary, this survey found generally positive attitudes among liver cancer specialists regarding the role of the NLCSP. However, most of the survey participants rated the NCLSP as needing improvement. The findings from this survey can provide relevant information and may help future health policy decisions.

\section{SUPPLEMENTARY MATERIAL}

Supplementary datas can be found with this article online http://www.e-jlc.org/html/https://doi.org/10.17998/ jlc.20.1.53.

\section{Conflicts of Interest}

The authors declare no conflicts of interest relevant to this article.

\section{REFERENCES}

1. Kim BH, Park JW. Epidemiology of liver cancer in South Korea. Clin Mol Hepatol 2018;24:1-9.

2. Kweon SS. Epidemiology of liver cancer in Korea. J Korean Med Assoc 2019;62:416-423.

3. Yoo KY. Cancer control activities in the Republic of Korea. Jpn J Clin Oncol 2008;38:327-333.

4. Suh M, Song S, Cho HN, Park B, Jun JK, Choi E, et al. Trends in Participation Rates for the National Cancer Screening Program in Korea, 2002-2012. Cancer Res Treat 2017:49:798-806.

5. Kim Y, Jun JK, Choi KS, Lee HY, Park EC. Overview of the National Cancer screening programme and the cancer screening status in Korea. Asian Pac J Cancer Prev 2011;12:725-730.
6. Korean Liver Cancer Association; National Cancer Center. 2018 Korean Liver Cancer Association-National Cancer Center Korea Practice Guidelines for the Management of Hepatocellular Carcinoma. Gut Liver 2019;13:227-299.

7. Jung KW, Won YJ, Kong HJ, Oh CM, Shin A, Lee JS. Survival of Korean adult cancer patients by stage at diagnosis, 2006-2010: national cancer registry study. Cancer Res Treat 2013;45:162-171.

8. Kwon JW, Tchoe HJ, Lee J, Suh JK, Lee JH, Shin S. The impact of national surveillance for liver cancer: Results from Real-World Setting in Korea. Gut Liver 2020;14:108-116.

9. Jung M. National Cancer Screening Programs and evidence-based healthcare policy in South Korea. Health policy 2015;119:26-32.

10. Shim JJ, Park HJ, Kim JW, Hwang EJ, Lee CK, Jang JY, et al. The Korean National Liver Cancer Surveillance Program: Experience of a Single Healthcare Center in 2011. Korean J Med 2013;84:672680.

11. Choi IS, Oh CH, Park SY, Ahn SE, Park SJ, Choi HR, et al. Incidence of primary liver cancer in subjects with chronic hepatitis $B$ in Korean National Liver Cancer Screening Program. J Liver Cancer 2017;17:136-143.

12. Suh $M$, Choi KS, Park B, Lee YY, Jun JK, Lee DH, et al. Trends in Cancer Screening Rates among Korean Men and Women: Results of the Korean National Cancer Screening Survey, 2004-2013. Cancer Res Treat 2016;48:1-10.

13. Choi MH, Jung SE, Choi Jl, Jeong WK, Kim HC, Kim Y, et al. Quality management of ultrasound surveillance for hepatocellular carcinoma under the Korean National Cancer Screening Program. J Ultrasound Med 2018;37:245-254.

14. Kim DY, Kim HJ, Jeong SE, Kim SG, Kim HJ, Sinn DH, et al. The Korean guideline for hepatocellular carcinoma surveillance. J Korean Med Assoc 2015;58:385-397.

15. Na SK, Song BC. Development and surveillance of hepatocellular carcinoma in patients with sustained virologic response after antiviral therapy for chronic hepatitis C. Clin Mol Hepatol 2019;25:234-244.

16. Zhang $X$, Wong GL, Wong VW. Application of transient elastography in nonalcoholic fatty liver disease. Clin Mol Hepatol 2019 Nov 8. doi: 10.3350/cmh.2019.0001n. [Epub ahead of print]. 
Supplementary Table 1. Survey results stratified according to year of experiences among hepatologists $(n=72)$

\begin{tabular}{|c|c|c|c|}
\hline Question & $\begin{array}{l}\text { Experience less } \\
\text { than } 10 \text { years } \\
\quad(n=30)\end{array}$ & $\begin{array}{l}\text { Experience more } \\
10 \text { years } \\
(n=42)\end{array}$ & $P$-value \\
\hline $\begin{array}{l}\text { Do you agree that hepatocellular carcinoma surveillance in high risk patients can } \\
\text { lower the risk of hepatocellular carcinoma-related death? }\end{array}$ & & & 0.37 \\
\hline Very agree & 80 & 67 & \\
\hline Agree & 20 & 31 & \\
\hline Disagree & 0 & 2 & \\
\hline $\begin{array}{l}\text { Do you know about the current National Liver Cancer Screening Program in } \\
\text { Korea? }\end{array}$ & & & 0.78 \\
\hline Know very well & 83 & 86 & \\
\hline Know well & 17 & 14 & \\
\hline $\begin{array}{l}\text { Do you think the National Liver Cancer Screening Program currently implemented } \\
\text { in Korea contributes in lowering hepatocellular carcinoma-related deaths? }\end{array}$ & & & 0.031 \\
\hline Very contributing & 37 & 14 & \\
\hline Contribute to some extent & 53 & 76 & \\
\hline Not contributing & 0 & 10 & \\
\hline $\begin{array}{l}\text { How many points can you give to the National Liver Cancer Screening Program? } \\
\text { (median, quartile) }\end{array}$ & $8(7-8)$ & $7(6-8)$ & $<0.001$ \\
\hline $\begin{array}{l}\text { Do you think current National Liver Cancer Screening Program target population } \\
\text { is appropriate target? }\end{array}$ & & & 0.16 \\
\hline Very appropriate & 13 & 3 & \\
\hline Appropriate & 60 & 64 & \\
\hline Inappropriate & 23 & 33 & \\
\hline Very inappropriate & 3 & 0 & \\
\hline Do you think 'cirrhosis over 40 years of age' is appropriate target? (yes) & 70 & 76 & 0.55 \\
\hline $\begin{array}{l}\text { Do you think 'chronic hepatitis B virus infection over } 40 \text { years of age' is appropriate } \\
\text { target? (yes) }\end{array}$ & 80 & 74 & 0.54 \\
\hline $\begin{array}{l}\text { Do you think 'chronic hepatitis C virus infection over } 40 \text { years of age' is appropriate } \\
\text { target? (yes) }\end{array}$ & 67 & 67 & 1.00 \\
\hline \multicolumn{4}{|l|}{ Agreements on surveillance target } \\
\hline Patients with liver cirrhosis should be surveillance targets regardless of age & 97 & 86 & 0.12 \\
\hline Starting age for surveillance should be different for men and women & 0 & 29 & 0.001 \\
\hline $\begin{array}{l}\text { Chronic hepatitis patients (e.g., fatty liver, alcoholic liver disease) with advanced } \\
\text { fibrosis should be surveillance targets regardless of age }\end{array}$ & 73 & 76 & 0.78 \\
\hline $\begin{array}{l}\text { Anti-HCV positive patients without advanced fibrosis should not be included as } \\
\text { a surveillance target regardless of age }\end{array}$ & 20 & 24 & 0.70 \\
\hline $\begin{array}{l}\text { Chronic hepatitis C patients who achieved sustained virological response and } \\
\text { without advanced fibrosis should not be included as surveillance targets } \\
\text { regardless of age }\end{array}$ & 37 & 29 & 0.46 \\
\hline $\begin{array}{l}\text { Chronic hepatitis B patients without advanced fibrosis should not be included as } \\
\text { surveillance targets regardless of age }\end{array}$ & 10 & 7 & 0.66 \\
\hline $\begin{array}{l}\text { Did you know the target population selection process of the National Liver Cancer } \\
\text { Screening Program? (yes) }\end{array}$ & 57 & 59 & 0.87 \\
\hline
\end{tabular}


Supplementary Table 1. Continued

\begin{tabular}{|c|c|c|c|}
\hline Question & $\begin{array}{l}\text { Experience less } \\
\text { than } 10 \text { years } \\
\quad(n=30)\end{array}$ & $\begin{array}{l}\text { Experience more } \\
10 \text { years } \\
(n=42)\end{array}$ & $P$-value \\
\hline $\begin{array}{l}\text { Do you think the target population selection process of the National Liver Cancer } \\
\text { Screening Program should be improved? }\end{array}$ & & & 0.54 \\
\hline Very necessary & 17 & 29 & \\
\hline Necessary & 73 & 62 & \\
\hline Not necessary & 10 & 9 & \\
\hline \multicolumn{4}{|l|}{ Agreements on opinions about reasons why selection process need improvement } \\
\hline $\begin{array}{l}\text { The screening targets identified by disease classification codes may not match } \\
\text { true surveillance targets }\end{array}$ & 40 & 79 & 0.001 \\
\hline There can be a privacy violation problem & 10 & 21 & 0.20 \\
\hline $\begin{array}{l}\text { The current process identifies individuals who use medical services, and } \\
\text { paradoxically, misses individuals who do not use medical services }\end{array}$ & 77 & 83 & 0.48 \\
\hline \multicolumn{4}{|l|}{ Agreements on opinions about how selection process should be improved } \\
\hline $\begin{array}{l}\text { Disease classification codes used to select the target population should be } \\
\text { simplified }\end{array}$ & 37 & 41 & 0.74 \\
\hline Register target population as cancer or rare/incurable disease & 43 & 41 & 0.80 \\
\hline $\begin{array}{l}\text { Minimize national program and increase private sector program using more } \\
\text { incentives }\end{array}$ & 43 & 55 & 0.33 \\
\hline The foremost priority for improvement & & & 0.35 \\
\hline Surveillance target & 17 & 14 & \\
\hline Target identification process & 13 & 17 & \\
\hline Surveillance methods & 33 & 14 & \\
\hline Screening rate & 7 & 19 & \\
\hline Quality control & 7 & 10 & \\
\hline Duplication problem & 23 & 21 & \\
\hline Others & 0 & 5 & \\
\hline \multicolumn{4}{|l|}{ Agreements on area that need improvement } \\
\hline Surveillance target & 63 & 71 & 0.46 \\
\hline Target identification process & 57 & 64 & 0.51 \\
\hline Surveillance methods & 50 & 50 & 1.00 \\
\hline Screening rate & 60 & 52 & 0.52 \\
\hline Quality control & 47 & 60 & 0.28 \\
\hline Duplication problem & 57 & 69 & 0.28 \\
\hline
\end{tabular}

Values are presented as \%. 


\section{전문가(대한간암학회 회원 대상) 의견 수집 을 위한 설문지}

1. 선생님의 전문 진료과는 무엇입니까?

한 개의 타원형만 표시합니다.

$\longrightarrow$ 내과-소화기

$\longrightarrow$ 내과-소화기외 분과 혹은 일반의

외과

영상의학과

$\longrightarrow$ 가정의학과

방사선종양학과

$\longrightarrow$ 병리과

기타:

2. 전문의 취득년도는 언제입니까?

3. 현재 진료하시는 기관은 어디입니까?

한 개의 타원형만 표시합니다.

대학병원

종합병원

$\longrightarrow$ 개인의원

$\longrightarrow$ 건강검진센터

$\longrightarrow$ 기타: 
4. 간암 고위험군을 대상으로 간암 선별검사(검진)을 시행하는 것이 간암 사망 위험을 낮춘다고 생각하십니까?

한 개의 타원형만 표시합니다.

$\bigcirc$ 매우 동의한다

$\bigcirc$ 동의한다

동의하지 않는다

$\bigcirc$ 전혀 동의하지 않는다

5. 현재 우리나라에서 시행되고 있는 국가 간암 검진 사업에 대해 알고 계십니까?

한 개의 타원형만 표시합니다.

$\longrightarrow$ 잘 알고 있다.

$\longrightarrow$ 어느정도 알고있다.

$\bigcirc$ 잘 모른다

$\bigcirc$ 전혀 모른다

6. 현재 우리나라에서 시행되고 있는 국가 간암 검진 사업은 우리나라 간암 사망위험을 낮추는데 기여하고 있다고 생각하십니까?

한 개의 타원형만 표시합니다.

$\square$ 매우 기여하고 있다

$\longrightarrow$ 어느정도 기여하고 있다

$\bigcirc$ 기여하지 못하고 있다

$\bigcirc$ 전혀 기여하지 못하고 있다

7. 현재 우리나라에서 시행되고 있는 국가 간암 검진 사업에 몇 점을 주시겠습니까? (최 저 0점-최고 10점) 
8. 현재 국가 간암 검진 대상자는 만 40 세 이상 남녀 중 간경변증, B형간염 바이러스, C 형간염 바이러스 보유자들입니다. 이 대상군은 적절하다고 생각하십니까?

한 개의 타원형만 표시합니다.

매우 적절하다

적절하다

적절하지 않다

매우 적절하지 않다

9. 현재 대상자가 적절하지 않다고 생각하시면 적절하지 않다고 생각하시는 모든 경우 를 선택하여 주십시요

해당 사항에 모두 표시하새요.

$\square$ 만 40 세 이상 간경변증

$\square$ 만 40 세 이상 B형간염 바이러스 보유자

$\square$ 만 40세 이상 C형간염 바이러스 보유자

10. 다음은 간암 검진 대상자에 대한 의견들입니다. 동의하시는 모든 경우를 선택하여 주십시요

해당 사항에 모두 표시하세요.

$\square$ 간경변증은 나이 제한이 없어야 한다

$\square$ 간암 검진 대상자의 시작 연령은 남/녀가 달라야 한다

$\square$ 진행성 섬유화가 동반된 만성간질환(지방간염, 알코올 간질환, 만성 바이러스 간염 등)은 나이 제한없이 포함되어야 한다

$\square$ 진행성 섬유화가 동반되지 않은 c형 간염바이러스 항체 양성 환자는 나이 제한없이 포함 되지 않아야 한다

$\square$ 진행성 섬유화가 동반되지 않았으며, 치료로 완전 바이러스 반응이 획득된 만성 C형 간염 환자는 나이 제한없이 포함되지 않아야 한다

다

진행성 섬유화가 동반되지 않은 만성 B형 간염 환자는 나이 제한없이 포함되지 않아야 한 기타: 
11. 현재 국가 간암 건진 대상자 선정은 해당연도 전 2 년간 간암 발생 고위험군 해당자이며, 간암 발생 고위험군은 B형 간염바이러스 항 원 양성, C형 간염바이러스 항체 양성, B형 또 는 C형 간염바이러스에 의한 만성 간질환 환자로서 해당하는 질병분류코드로 의료이용 을 한 경우로 규정하고 있습니다. 이러한 선정 방식을 알고 계셨습니까?

표 4 간암발생고위험군 질병코드

\begin{tabular}{|c|c|}
\hline 질 환 명 & 질병분류 코드(code) \\
\hline $\begin{array}{c}\text { 간경변증 } \\
\text { "**는 0, } 1,2,9 \text { 를 의미 }\end{array}$ & $\begin{array}{l}K 702, K 703(K 7030, K 7031), K 74, K 740\left(K 740^{*}\right), K 741\left(K 741^{*}\right), \\
K 742\left(K 742^{*}\right), K 743\left(K 743^{*}\right), K 744\left(K 744^{*}\right), K 745\left(K 745^{*}\right), K 746\left(K 746^{*}\right), \\
K 765, K 766\end{array}$ \\
\hline $\begin{array}{l}\mathrm{B} \text { 형 간염바이러스 항원 양성. } \\
\mathrm{C} \text { 형 간염바이러스 항체 양성 }\end{array}$ & B18, B180, B181(B1810, B1818), B182, B188, B189, Z225 \\
\hline $\begin{array}{c}\mathrm{B} \text { 형 또는 } \mathrm{C} \text { 형 간염바이러스에 } \\
\text { 의한 만성 간질환 환자 }\end{array}$ & B19, B190, B199 \\
\hline
\end{tabular}

한 개의 타원형만 표시합니다.

알고 있었다

모르고 있었다

12. 질병분류 코드를 이용한 대상자 선정 방식이 개선이 필요하다고 생각하십니까? 한 개의 타원형만 표시합니다.

매우 필요하다

$\bigcirc$ 필요하다

$\longrightarrow$ 필요하지 않다

$\longrightarrow$ 전혀 필요하지 않다 
13. 질병분류 코드를 이용한 대상자 선정 방식이 개선이 필요하다고 생각하신다면, 해 당하는 이유를 모두 선택해 주십시요.

\section{해당 사항에 모두 표시하세요.}

$\square$ 질병분류코드상 간암 건진 대상자는 간암 발생 고위험군과 일치하지 않을 수 있다

$\square$ 질병분류코드로 의료이용을 한 경우를 대상자로 선정하는 방식은 개인정보 위반 소지가 있다

$\square$ 질병분류코드로 의료이용을 한 경우를 대상자로 선정하면, 의료이용을 잘 하고 있는 환자 는 대상자로 선정되고, 역설적으로 의료이용을 잘 하고 있지 않은 환자들은 대상자에서 누락이 된다

기타:

14. 다음은 대상자 선정 방식 개선에 대한 의견들입니다. 동의하시는 의견을 모두 선택 하여 주십시요

\section{해당 사항에 모두 표시하세요.}

$\square$ 질병분류 코드 중 대상자인 질병분류 코드를 몇가지로 줄이고, 의료기관에서 간암 검진 대 상자는 특정 질병코드를 등록하게 한다

$\square$ 암 및 희귀질환 산정특례 등록 방식처럼, 간암 검진 대상자임을 의료기관에서 5 년마다 등 록하게 하고, 등록된 사람들에게 간암 검진을 5 년간 제공한다

$\square$ 간암 검진은 고위험군에 대한 검진이며, 고위험군 여부는 민감 개인정보이므로, 국가에서 대상자를 선정하는 현 방식은 철회하는 것이 맞고, 검진이 아닌 진료시에 간암 선별검사를 위 한 초음파 등 검사는 추가적인 진료비 혜택을 주는 방식으로 전환해야 한다

기타: 
15. 회원님께서 국가 간암 검진 사업을 담당하신다면 가장 우선적으로 개선할 부분은 어떤 항목이라고 생각하시는지 가장 중요한 한가지만 선택하여 주십시요

한 개의 타원형만 표시합니다.

$\square$ 대상 환자군 개선 (검진 대상자의 확대 또는 축소)

$\square$ 대상자 선정방식 개선(질병분류코드로 의료이용을 한 경우에 따른 선정방식의 개선) 검진 방법의 개선 (고위험군의 경우 초음파 외 CT/MRI의 허용, AFP외 PIVKA-II등 다른 종양표지자 검사 활용, 초고위험군은 3 개월 간격 검사 허용 등)

$\bigcirc$ 검진 수검률 증가(대국민 홍보 및 수검자 혜택 증가 등을 통한 수검률 증가)

$\longrightarrow$ 검진 질관리 사업(검진 사업의 질 담보)

$\bigcirc$ 국가 간암 검진과 진료 영역의 중복 문제 해결(국가 검진을 받는 사람들과 의료기관에 서 진료받는 환자들의 이중 간암 검진 문제 해결)

$\bigcirc$ 기타:

16. 회원님께서 국가 간암 검진 사업 중 개선이 필요한 항목이라고 생각하시는 항목이 있다면, 해당하는 항목을 모두 선택하여 주십시요

해당 사항에 모두 표시하세요.

대상 환자군 개선 (검진 대상자의 확대 또는 축소)

대상자 선정방식 개선(질병분류코드로 의료이용을 한 경우에 따른 선정방식의 개선)

$\square$ 검진 방법의 개선 (고위험군의 경우 초음파 외 CT/MRI의 허용, AFP외 PIVKA-II등 다른 종 양표지자 검사 활용, 초고위험군은 3 개월 간격 검사 허용 등)

$\square$ 검진 수검률 증가(대국민 홍보 및 수검자 혜택 증가 등을 통한 수검률 증가)

$\square$ 검진 질관리 사업(검진 사업의 질 담보)

$\square$ 국가 간암 검진과 진료 영역의 중복 문제 해결(국가 검진을 받는 사람들과 의료기관에서 진료받는 환자들의 이중 간암 검진 문제 해결)

기타:

17.

한 개의 타원형만 표시합니다.

\section{옵션 1}


Journal of Liver Cancer

Volume 20 Number 1, March 2020

Supplementary Fig 1. Continued

18. 국가 간암 검진과 관련하여 제안하시고 싶은 의견을 자유롭게 기술해 주십시오.

이 콘텐츠는 Google이 만들거나 승인하지 않았습니다.

Google 설문지 